\title{
Physical and Mechanical Properties of Methyl Methacrylate-Impregnated Wood from Three Fast-Growing Tropical Tree Species ${ }^{1}$
}

\author{
Yusuf Sudo Hadi $\mathbb{C}^{2, \dagger} \cdot$ Muh Yusram Massijaya ${ }^{2} \cdot$ Lukmanul Hakim Zaini $^{2} \cdot$ Rohmah Pari ${ }^{3}$
}

\begin{abstract}
Timber from plantation forests has inferior physical and mechanical properties compared to timber from natural forest because it is mostly from fast-growing tree species that are cut at a young age. Filling cell voids with methyl methacrylate (MMA) can improve the wood properties. The purpose of this study was to determine the physical and mechanical properties of MMA-impregnated wood from three fast-growing wood species, namely jabon (Anthocephalus cadamba (Roxb.) Miq.), mangium (Acacia mangium Willd) and pine (Pinus merkusii Jungh. \& de Vriese). Wood samples were either immersed in MMA monomer or impregnated with it and then heated to induce the polymerization process. Jabon, which was the lowest density wood, had the highest polymer loading, followed by pine and mangium. The physical and mechanical properties of samples were affected by wood species and the presence of MMA, with higher-density wood having better properties than wood with a lower density. Physical and mechanical properties of MMA wood were enhanced compared to untreated wood. Furthermore, the impregnation process was better than immersion process resulting the physical and mechanical properties. Based on MOR values, the MMA woods were one strength class higher compared to untreated wood with regard to Strength Classification of Indonesian Wood.
\end{abstract}

Keywords: methyl methacrylate wood, polymerization with heating, polymer loading, fast-growing wood species

\section{INTRODUCTION}

Log production in Indonesia reached 37.5 million $\mathrm{m}^{3}$ in 2016, and $85 \%$ of the wood came from plantation forests (Ministry of Environment and Forestry, 2017). This wood has inferior characteristics in terms of physical-mechanical properties and resistance to biodeterioration because the trees are cut at young ages (5 to 10 years old) (Hadi et al., 2015a), and the wood contains a lot of sapwood and juvenile wood, which have inferior characteristics compared with wood from more mature trees (Fajriani et al., 2013).

Wood properties can be improved through manufacturing glued laminated lumber (glulam) (Hendrik et al., 2016), impregnating cell voids with a polymer such as polystyrene (Hadi et al., 1998) or methyl methacrylate (MMA) (Hadi et al., 2013), phenol formaldehyde impregnation on soft-inner part of oil palm trunk (Hartono

\footnotetext{
${ }^{1}$ Date Received January 11, 2019, Date Accepted May 13, 2019

2 Forest Products Department, IPB University (Bogor Agricultural University), Bogor 16680, Indonesia

${ }^{3}$ Forest Products Research and Development Center, Bogor 16118, Indonesia

† Corresponding author: Yusuf Sudo Hadi (e-mail: yshadi@indo.net.id, ORCID: 0000-0002-2212-4501)
} 
Physical and Mechanical Properties of Methyl Methacrylate-Impregnated Wood from Three Fast-Growing Tropical Tree Species

et al., 2016), immersion treatment with pyroligneous liquor of sapwood (Won et al., 2016) and chemically modifying wood through acetylation (Hadi et al., 1995) or treatment with furfuryl alcohol (Hadi et al., 2005). Manufacturing glulam improves physical-mechanical properties of the wood, and additional treatment can also increase wood resistance to biodeterioration, including attack by subterranean termite, dry wood termite and fungus (Hadi et al., 2015b). In addition, MMA impregnated on four young tropical wood could increase the resistance of wood to subterranean termite attack during in-ground testing (Hadi et al., 2018).

The physical and mechanical properties of wood are improved through impregnation with MMA, which yields wood with better performance than untreated wood. Olpan and Guven (2001) reported that MMA polymer improves the mechanical properties of wood. In particular, Wang et al. (2012) found that MMA wood has better mechanical properties than untreated wood in terms of modulus of rupture (MOR), modulus of elasticity (MOE), compression strength and hardness. They also reported that the degree of polymer loading affects the physical and mechanical properties linearly. In a study of five hardwoods and one softwood polymerized with MMA, Ding et al. (2008) found that the density was increased between $45 \%$ and $130 \%$ depending on the species.

The other researchers Islam et al. (2011) made MMA treated wood with a cross-linker hexamethylene diisocyanate on five species of tropical light hardwood namely jelutong (Dyera costulata), terbulan (Endospermum diadenum), batai (Paraserianthes moluccana), rubber (Hevea brasiliensis), and pulai (Alstonia pneumatophora) were collected from a local forest in Sarawak, Malaysia, and the results showed that the MMA wood had improved volumetric swelling and dynamics Young's modulus. Kouba et al. (2012) made MMA hardened wood from fast growing poplar clones, and the results showed that the wood had hardness 2.5-4 times higher and superior abrasion resistance compared to the untreated wood.

The previous studies used tropical light hardwoods, and some wood species from temperate. Indonesia has been developing plantation forest reaching 10.8 million hectares, and average logs production during last five years reached over 30 million $\mathrm{m}^{3}$ with young and small diameter logs characteristics. The timber produced from plantation forest should be improved in terms of physical and mechanical properties.

Hadi et al. (2013) studied MMA-impregnated jabon wood and polymerization using ${ }^{60} \mathrm{Co}$ gamma ray and found improvement in the physical and mechanical properties. In a later study, Hadi et al. (2015a) found that the process could also increase resistance to subterranean termite attack, but the apparatus and production costs were expensive. Previously, Hadi et al. (1998) made four kinds of polystyrene-impregnated woods from Poland using heat treatment for the polymerization process, and the wood had much better resistant to termite attacks. Heat for the polymerization process can also be applied for manufacturing MMAimpregnated wood (Cho et al., 1974 and Lee, 1983). The purpose of this study was to determine the properties of MMA-impregnated wood made from tropical fast growing tree species with small diameter logs, namely jabon (Anthocephalus cadamba (Roxb.) Miq.), mangium (Acacia mangium Willd), and pine (Pinus merkusii Jungh. \& de Vriese) and compare the results to those of untreated wood as the control.

\section{MATERIALS and METHODS}

\subsection{Materials}

Wood of jabon, mangium, and pine from Bogor, Indonesia, were used to determine the physical and mechanical properties of MMA-impregnated wood. The trees were cut from plantation forest with age at 5-10 
years old, the diameter of logs was about $20 \mathrm{~cm}$, and the logs were cut into timbers with flat sawn pattern.

The physical properties tested were density, moisture content, volume shrinkage, and water absorption. The tests were using wood specimens with dimensions of $5 \mathrm{~cm}$ by $5 \mathrm{~cm}$ by $5 \mathrm{~cm}$ referring to ASTM D 4442-92 (ASTM, 1992) and ASTM D 2395-07 (ASTM, 2007). The mechanical properties tested were MOR, MOE, side hardness, and end hardness referring to British Standard (BS) 373:1957 (BS, 1957). The dimensions of specimen for MOE and MOR were $2 \mathrm{~cm}$ by $2 \mathrm{~cm}$ in cross section and $30 \mathrm{~cm}$ in longitudinal direction, and hardness was tested to specimen with dimension of $2 \mathrm{~cm}$ by $2 \mathrm{~cm}$ in cross section and $6 \mathrm{~cm}$ in longitudinal direction.

\subsection{Methods}

Filling cell voids with MMA monomer solution was done through immersion and impregnation processes. For the immersion process, air-dried wood samples were immersed in a MMA monomer solution for 24 hours. For the impregnation process, the wood samples were placed under vacuum at 5 atmospheres for 30 minutes and then immersed in an MMA monomer solution under pressure at 5 atmospheres for 30 minutes. The apparatus for immersion and impregnation processes are shown in Fig. 1. Each wood sample was wrapped in an aluminum sheet after MMA immersion or impregnation and heated in an oven at $60{ }^{\circ} \mathrm{C}$ for 48 hours. To accelerate polymerization process, the MMA solution was added with mepoxy, methyl ethyl ketone peroxide $\left(\mathrm{C}_{8} \mathrm{H}_{18} \mathrm{O}_{6}\right)$, at amount of 10/100 (v/v) of mepoxy/MMA. Afterward, the aluminum was removed and the wood samples were weighed for polymer-loading calculation. For purposes of comparison, untreated wood was included as the control, and each test was replicated with five samples for each treatment combination.

Polymer loading (PL) was determined through weighing the wood specimen before treatment at oven dried condition (W1), and then the oven dried weight of specimen was also determined after impregnation

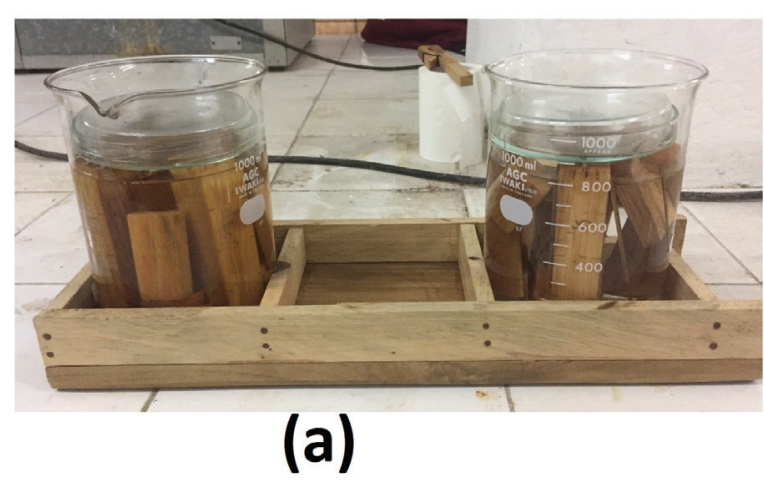

Fig. 1. Entering MMA monomer to the wood voids: (a) immersion- and (b) impregnation-process.

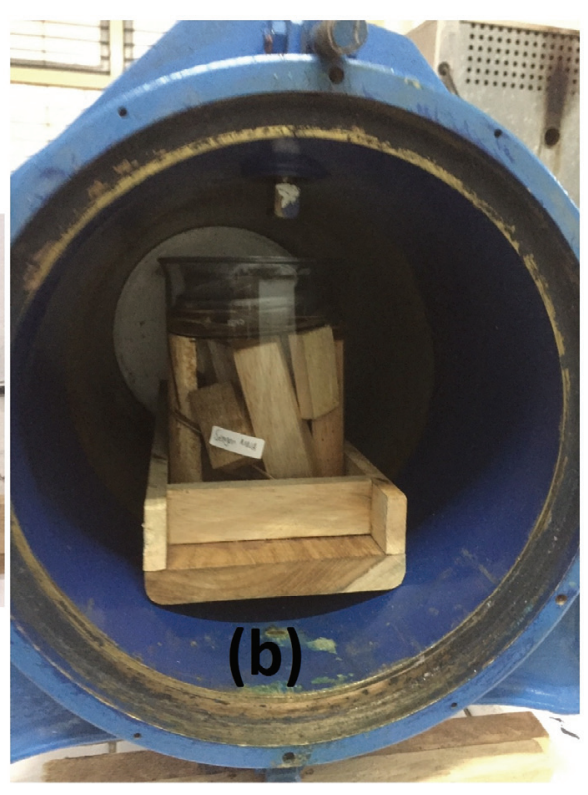


with MMA (W2). The PL was calculated using the following formula (1):

$$
\mathrm{PL}(\%)=(\mathrm{W} 2-\mathrm{W} 1) / \mathrm{W} 1 \times 100 \cdots \cdots(1)
$$

Moisture content (MC) was determined with oven dry weight method. The air dry specimen was weighed as initial weight (W3), and then put in the oven at temperature of $103 \pm 2{ }^{\circ} \mathrm{C}$ until constant weight as oven dry weight (W1). The MC was calculated by the following formula (2):

$$
\mathrm{MC}(\%)=(\mathrm{W} 3-\mathrm{W} 1) / \mathrm{W} 1 \times 100 \cdots \cdots(2)
$$

Wood density was determined through measuring volume of wood specimen at air dry condition (V1), and oven dry weight (W1), and the wood density was calculated as followed (3):

$$
\text { Wood density }\left(\mathrm{g} / \mathrm{cm}^{3}\right)=\mathrm{W} 1 / \mathrm{V} 1
$$

The wood specimens were immersed in water at room temperature for 48 hours, and then the specimens volume at wet condition was measured (V2). The specimens then were put in to the oven until reach oven dry condition, and the oven dry volumes were determined (V3). The volume shrinkage was calculated as followed (4):

$$
\text { Shrinkage }(\%)=(V 2-\text { V3) } / \text { V2 × } 100 \cdots(4)
$$

Water absorption was determined through weighing the specimen at air dry condition (W3), then it was immersed in water for 48 hours, and finally the weight was determined at wet condition (W4). Water absorption was calculated by the following formula (5):

Water absorption (\%)

$$
=(\mathrm{W} 4-\mathrm{W} 3) / \mathrm{W} 3 \times 100
$$

MOE and MOR were obtained by the bending tests by using an Instron Universal Testing Machine (type 3369). Testing was done through a single point load on the span of a sample with the distance between the points of support of the test piece was $28 \mathrm{~cm}$. Loading orientation was perpendicular to tangential face of the test specimen, and a loading speed of $3.5 \mathrm{~mm} / \mathrm{min}$. The MOE and MOR were calculated using formulas as follows (6 and 7):

$$
\begin{gathered}
\operatorname{MOE}\left(\mathrm{kgf} / \mathrm{cm}^{2}\right)=\left(\Delta \mathrm{PL}^{3}\right) /\left(4 \Delta \mathrm{Ybh}^{3}\right) \cdots \cdots(6) \\
\operatorname{MOR}\left(\mathrm{kgf} / \mathrm{cm}^{2}\right)=(3 \mathrm{PL}) /\left(2 \mathrm{bh}^{2}\right) \cdots \cdots \cdot(7)
\end{gathered}
$$

where $\Delta \mathrm{P}$ is the difference between the upper and lower loading limits in the proportional limit region (kgf), $\Delta \mathrm{Y}$ is the deflection with respect to $\Delta \mathrm{P}(\mathrm{cm}), \mathrm{L}$ is span $(\mathrm{cm}), \mathrm{b}$ is the width of the test specimen $(\mathrm{cm}), \mathrm{h}$ is the thickness of the specimen $(\mathrm{cm})$, and $\mathrm{P}$ is the maximum loading (kgf).

Hardness was determined through the Janka test which was done using a $1.128+0.005 \mathrm{~cm}$ diameter of hemispherical steel ball in order to determine the required load until a depth of $0.564 \mathrm{~cm}$ achieved upon test specimen surface. Side hardness was determined if the loading orientation was perpendicular to tangential face of the test specimen, and end hardness was parallel to longitudinal grain orientation.

Based on the MOR value, the wood was classified into a strength classification of Indonesian wood as described by Martawijaya et al. (2005) and shown in Table 1.

\subsection{Data analysis}

To analyze the effect of treatments upon all responds, a completely randomized factorial $3 \times 3$ design was used to analyze the data, and the mathematical model for this data analysis could be expressed as followed (8): 
Table 1. Strength classification of Indonesian wood

\begin{tabular}{ccc}
\hline Strength class & \multicolumn{1}{c}{ Specific gravity } & MOR $\left(\mathrm{kgf} / \mathrm{cm}^{2}\right)$ \\
\hline \hline I & $>0.90$ & $>1100$ \\
II & $0.60-0.90$ & $725-1100$ \\
III & $0.40-0.60$ & $500-725$ \\
IV & $0.30-0.40$ & $360-500$ \\
V & $<0.30$ & $<360$ \\
\hline
\end{tabular}

$$
\mathrm{y}_{\mathrm{ijk}}=\mu+\alpha_{\mathrm{i}}+\beta_{\mathrm{j}}+\alpha_{\mathrm{i}} \beta_{\mathrm{j}}+\varepsilon_{\mathrm{ijk}}
$$

where: $\mathrm{y}_{\mathrm{ijk}}=$ observation value at $\mathrm{i}$ treatment, $\mathrm{j}$ block, and $\mathrm{k}$ replication; $\mu=$ mean value of observation; $\alpha_{\mathrm{i}}$ $=$ effect of wood species at $\mathrm{i}$ level; $\beta_{\mathrm{j}}=$ effect of treatment at $\mathrm{j}$ level; $\alpha_{\mathrm{i}} \beta_{\mathrm{j}}=$ effect of interaction between wood species at $\mathrm{i}$ level and treatment at $\mathrm{j}$ level; $\varepsilon_{\mathrm{ijk}}=$ error at $\mathrm{i}$ wood species, $\mathrm{j}$ treatment, and $\mathrm{k}$ replication. The data was analyzed with Microsoft Excel and SPSS (Statistical Product and Service Solution) version 22.

The first factor was wood species (jabon, mangium, and pine) and the second factor was treatment, namely the process by which the MMA monomer solution was added to the cell voids (immersion and impregnation), with untreated wood as the control. Duncan's multiple range test was used for further analysis if a factor was significantly different at p 0.05 or less. The least significant range, $\mathrm{R}_{\mathrm{p}}$, for subsets of $\mathrm{p}$ sample means is given by (9):

$$
\mathrm{R}_{\mathrm{p}}=\mathrm{r}_{\mathrm{p}}\left(\mathrm{s}^{2} / \mathrm{n}\right)^{0.5}
$$

where: $r_{p}=$ the least significant studentized range; $s^{2}$ $=$ the error mean square; $\mathrm{n}=$ number sample for each treatment.

\section{RESULTS and DISCUSSION}

\subsection{Physical properties}

The physical properties associated with each wood species and treatment, including polymer loading, density, moisture content, volume shrinkage, and water absorption are shown in Table 2. The results of variance analysis are shown in Table 3. If interaction factor is not significantly different, Duncan's multi range test

Table 2. Physical properties of each wood species and treatment ${ }^{\mathrm{a}}$

\begin{tabular}{lcccc}
\hline Response & Treatment & Jabon & Mangium & Pine \\
\hline \hline Polymer loading (\%) & Immersion & $13.39(2.10)$ & $8.66(1.27)$ & $10.94(1.50)$ \\
& Impregnation & $23.75(4.63)$ & $14.62(1.15)$ & $17.80(4.55)$ \\
\hline Density $\left(\mathrm{g} / \mathrm{cm}^{3}\right)$ & Untreated & $0.33(0.01)$ & $0.57(0.02)$ & $0.64(0.04)$ \\
& Immersion & $0.37(0.01)$ & $0.62(0.02)$ & $0.71(0.04)$ \\
& Impregnation & $0.41(0.01)$ & $0.65(0.02)$ & $0.75(0.04)$ \\
\hline Moisture content (\%) & Untreated & $12.14(0.42) \mathrm{e}$ & $13.44(0.79) \mathrm{e}$ & $12.52(0.55) \mathrm{f}$ \\
& Immersion & $11.38(0.68) \mathrm{d}$ & $10.75(0.14) \mathrm{c}$ & $7.78(0.16) \mathrm{b}$ \\
& Impregnation & $6.29(0.17) \mathrm{a}$ & $5.88(0.17) \mathrm{a}$ & $7.60(0.45) \mathrm{b}$ \\
\hline Volume shrinkage (\%) & Untreated & $3.43(0.35) \mathrm{c}$ & $5.75(0.43) \mathrm{d}$ & $5.28(0.60) \mathrm{d}$ \\
& Immersion & $1.79(0.17) \mathrm{a}$ & $3.47(0.31) \mathrm{c}$ & $2.85(0.36) \mathrm{b}$ \\
& Impregnation & $1.56(0.54) \mathrm{a}$ & $2.08(0.20) \mathrm{a}$ & $2.68(0.31) \mathrm{b}$ \\
\hline Water absorption (\%) & Untreated & $84.11(7.49) \mathrm{f}$ & $49.34(3.45) \mathrm{de}$ & $53.47(4.93) \mathrm{de}$ \\
& Immersion & $80.95(4.97) \mathrm{f}$ & $32.77(8.59) \mathrm{b}$ & $46.40(5.35) \mathrm{cd}$
\end{tabular}

\footnotetext{
${ }^{a}$ Values in parentheses are standard deviations. Values followed by the same letter within the rows in each respond
} are not statistically different regarding to Duncan's multi range test. 
Table 3. Analysis of variance results ( $F$ test) for physical properties

\begin{tabular}{lccc}
\hline Response & Wood species (A) & Treatment (B) & Interaction (AB) \\
\hline \hline Polymer loading (\%) & $* *$ & $* *$ & NS \\
Density $\left(\mathrm{g} / \mathrm{cm}^{3}\right)$ & $* *$ & $* *$ & NS \\
Moisture content (\%) & $* *$ & $* *$ & $* *$ \\
Shrinkage (\%) & $* *$ & $* *$ & $* *$ \\
Water absorption (\%) & $* *$ & $* *$ & $* *$ \\
\hline
\end{tabular}

** Highly significantly different $(\mathrm{P} \leq 0.01)$; NS, not significantly different.

Table 4. Further data analysis of wood species factor in physical and mechanical properties ${ }^{\text {a }}$

\begin{tabular}{lccc}
\hline Wood species & Polymer loading $(\%)$ & Density $\left(\mathrm{g} / \mathrm{cm}^{3}\right)$ & End hardness $\left(\mathrm{kgf} / \mathrm{cm}^{2}\right)$ \\
\hline \hline Jabon & $18.57 \mathrm{a}$ & $0.37 \mathrm{a}$ & $303 \mathrm{a}$ \\
Mangium & $11.64 \mathrm{~b}$ & $0.61 \mathrm{~b}$ & $453 \mathrm{~b}$ \\
Pine & $14.37 \mathrm{c}$ & $0.70 \mathrm{c}$ & $501 \mathrm{c}$ \\
\hline
\end{tabular}

${ }^{a}$ Values followed by the same letter within a column are not statistically different.

Table 5. Further data analysis of treatment factor in physical and mechanical properties ${ }^{\text {a }}$

\begin{tabular}{lccc}
\hline Treatment & Polymer loading (\%) & Density $\left(\mathrm{g} / \mathrm{cm}^{3}\right)$ & End hardness $\left(\mathrm{kgf} / \mathrm{cm}^{2}\right)$ \\
\hline \hline Untreated & - & $0.51 \mathrm{a}$ & $382 \mathrm{a}$ \\
Immersion & $11.00 \mathrm{a}$ & $0.57 \mathrm{~b}$ & $425 \mathrm{~b}$ \\
Impregnation & $18.72 \mathrm{~b}$ & $0.60 \mathrm{c}$ & $450 \mathrm{c}$ \\
\hline
\end{tabular}

${ }^{a}$ Values followed by the same letter within a column are not statistically different.

for further analysis of wood species and treatment factors are presented in Tables 4 and 5 . The wood densities of untreated jabon, mangium, and pine were $0.33,0.57$, and $0.64 \mathrm{~g} / \mathrm{cm}^{3}$, respectively (Table 2 ). These densities fell within the low (jabon) to medium (mangium, and pine) categories. All the trees from which samples were derived are fast-growing species and were cut at 5 to 10 years old in this study. Although very young trees such as these do not provide high-quality wood, they have recently become very popular for the wood industry in Indonesia.

As shown in Table 2, polymer loading of jabon wood through the impregnation process reached $23.8 \%$ in this study. This value was lower than that found by Hadi et al. (2013), who reported polymer loading of $28.1 \%$ using a polymerization process with ${ }^{60} \mathrm{Co}$ gamma ray at $30 \mathrm{kGy}$ radiation dose and a 30-minute impregnation period. In the current study, the polymerization process used heat and took 48 hours, possibly allowing some of the solution to escape the polymerization process. The results of polymer loading with the impregnation process were better than those obtained by Hadi et al. (2008). In that study, betung bamboo (Dendrocalamus asper) was impregnated with MMA and radiated with ${ }^{60} \mathrm{Co}$ gamma ray at $40 \mathrm{kGy}$ was used for the polymerization process, resulting in $11 \%-13 \%$ polymer loading. Bamboo had a higher density than jabon wood, and the monomer styrene consequently had greater difficulty entering the cell void space.

According to Table 3 wood species, treatment, and interaction between wood species and treatment factors affected nearly all physical properties, but the interaction 
factor did not significantly affect polymer loading and wood density. As shown in Table 4 polymer loadings among wood species were different each other. Jabon wood had the highest polymer loading because it had the lowest density; more space was available between the wood cells for MMA to enter. Mangium wood had a lower polymer loading because it had a higher density than jabon wood. Pine had more polymer loading than mangium despite its higher density. Pine belongs to the conifer class, which has more simple anatomical characteristics compared to mangium, which belongs to the broadleaf class. Softwood is mostly arranged by tracheid cells while hardwood more complex which is composed of at least five basic cells namely vessel, fibers, parenchyma, tracheid and epithelial cells. This result was in line with Ding et al. (2008), who reported that the enhanced density due to polymerized MMA depended on the wood species. On average, the polymer loading through the impregnation process was $18.7 \%$, which was higher than through the immersion process (11.0\%). The pressure effect appeared to force more MMA monomer into the cell voids in the impregnation process.

Regarding to Table 3 wood species and treatment factors affected wood density. Table 4 showed that densities among the three wood species were different each other, the lowest density was jabon, followed by mangium and pine, and these densities were equal to the initial densities of each wood species. In term of treatment factor, impregnation process had higher density gain compared to immersion process because the impregnation used pressure to enhance MMA entering void in wood even the pressure was relatively short time compared to immersion process. The density gains of MMA wood samples were equal to those polymer loadings.

As shown in Table 3, the moisture content of wood samples was affected by the wood species, treatment, and the interaction factor. Following further data analysis of Duncan's multi range test, the results shown in Table 2 indicated by the same letters in the rows of moisture content, MMA impregnation process had the lowest moisture content, followed by MMA immersion process and untreated woods, and the three treated woods were significantly different each other. The impregnation process was associated with the lowest moisture content, because the wood sample contained more MMA polymer, and bonding water could be blocked from being adsorbed to the cell wall. In contrast, untreated wood could adsorb more bonding water by the cell wall without any handicaps.

As shown in Table 3, wood shrinkage was affected by the wood species, treatment, and the interaction factors. Following further data analysis of Duncan's multi range test, jabon wood had the lowest shrinkage because of having the lowest density, and consequently consisting of the smallest amount of cell wall materials. This matters could be expressing that jabon had the smallest potential to shrink or swell. In another factor, it could be mentioned that MMA-treated wood had less shrinkage compared to untreated wood. MMA is hydrophobic, and it could block wood from adsorbing water, resulting in less shrinkage. In addition, the presence of MMA in the cell void could prevent wood from shrinking. In other words, MMA wood had better dimensional stability than untreated wood, and impregnation process was better than immersion process. This result was in line with Ding et al. (2012), who reported that treatment by impregnation with MMA effectively improved the dimensional stability of wood from six fast-growing hybrid poplar clones.

Table 3 shows that wood species, treatment and the interaction factors affected water absorption, and following further data analysis of multi range test indicated that the three wood species were different each other. As shown in Table 2, jabon wood had the greatest water absorption because of its lowest density, with a large cell void space resulting in a higher potential 
for free water to be absorbed. Mangium wood had lower water absorption because of its higher wood density compared to jabon wood. Further data from Martawijaya et al. (2005) and Prabawa (2005) mentioned that wood cell sizes of pine, mangium and jabon in terms of length were $5,457 \mu \mathrm{m}, 782 \mu \mathrm{m}$ and $1,979 \mu \mathrm{m}$, respectively, for diameter were $49 \mu \mathrm{m}, 22 \mu \mathrm{m}$ and $54 \mu \mathrm{m}$, respectively, for wall thickness were $4 \mu \mathrm{m}, 2.8 \mu \mathrm{m}$ and $3.2 \mu \mathrm{m}$, respectively, and for lumen diameter were $41 \mu \mathrm{m}, 16.4$ $\mu \mathrm{m}$ and $47.6 \mu \mathrm{m}$, respectively. The biggest lumen diameter belonged to jabon, and followed by pine and mangium, and water absorption values of the three wood species were also reflecting to the lumen diameter as well.

In general, higher wood density appeared to lead to higher moisture content, higher shrinkage, and lower water absorption. For the other factor, untreated wood was shown to have differed from MMA wood in terms of water absorption. MMA treatment resulted in wood samples having lower water absorption, because the
MMA filled the cell void space and could block intake of free water by the cell. Furthermore, it could be mentioned that the three treated woods were significantly different each other, and the impregnation process had the lowest water absorption because of more MMA polymer loading. In general, it could be resumed that physical properties of MMA-treated wood were better than untreated wood, and the impregnation process was better performance than immersion process.

\subsection{Mechanical properties}

The values for the mechanical properties MOR, MOE, side hardness, and end hardness are shown in Table 6 , analysis of variance result is shown in Table 7 . If interaction factor is not significantly different, Duncan's multi range test for further analysis are shown in Tables 4 and 5. Wood failure of tested specimens for MOR and MOE are shown in Fig. 2, for side- and end-hardness are shown in Fig. 3.

Table 6. Mechanical properties of each wood species and treatment ${ }^{a}$

\begin{tabular}{|c|c|c|c|c|}
\hline Response & Treatment & Jabon & Mangium & Pine \\
\hline \multirow{3}{*}{$\operatorname{MOR}\left(\mathrm{kgf} / \mathrm{cm}^{2}\right)$} & Untreated & 426 (29)a & $564(32) b$ & 549 (27)b \\
\hline & Immersion & $512(35) b$ & 815 (37)c & $780(18) \mathrm{c}$ \\
\hline & Impregnation & 563 (49)b & $889(54) d$ & 912 (45)d \\
\hline \multirow{3}{*}{ Strength class } & Untreated & IV & III & III \\
\hline & Immersion & III & II & II \\
\hline & Impregnation & III & II & II \\
\hline \multirow{3}{*}{$\operatorname{MOE}\left(1,000 \mathrm{kgf} / \mathrm{cm}^{2}\right)$} & Untreated & 49.2 (2.9)a & $76.8(3.3) \mathrm{d}$ & $75.6(1.8) \mathrm{d}$ \\
\hline & Immersion & $54.5(2.6) \mathrm{b}$ & 91.7 (1.5)e & 97.5 (4.0)fg \\
\hline & Impregnation & 60.7 (3.7)c & 93.9 (4.2)ef & 99.9 (6.9)g \\
\hline \multirow{3}{*}{ Side hardness $\left(\mathrm{kgf} / \mathrm{cm}^{2}\right)$} & Untreated & 146 (14)a & 308 (19)c & $346(25) d$ \\
\hline & Immersion & 169 (17)ab & 367 (5)de & 439 (27)f \\
\hline & Impregnation & 176 (17)b & 373 (17)e & 452 (28)f \\
\hline \multirow{3}{*}{ End hardness $\left(\mathrm{kgf} / \mathrm{cm}^{2}\right)$} & Untreated & $289(26)$ & $402(20)$ & $456(31)$ \\
\hline & Immersion & 298 (19) & 462 (33) & $516(27)$ \\
\hline & Impregnation & 322 (18) & 496 (30) & $532(36)$ \\
\hline
\end{tabular}

\footnotetext{
${ }^{a}$ Values in parentheses are standard deviations. Values followed by the same letter within the rows in each respond
} are not statistically different regarding to Duncan's multi range test. 
Table 7. Analysis of variance results (F test) for mechanical properties

\begin{tabular}{lccc}
\hline Response & Wood species (A) & Treatment (B) & Interaction (AB) \\
\hline \hline MOR $\left(\mathrm{kgf} / \mathrm{cm}^{2}\right)$ & $* *$ & $* *$ & $* *$ \\
MOE $\left(1,000 \mathrm{kgf} / \mathrm{cm}^{2}\right)$ & $* *$ & $* *$ & $* *$ \\
Side hardness $\left(\mathrm{kgf} / \mathrm{cm}^{2}\right)$ & $* *$ & $* *$ & NS \\
End hardness $\left(\mathrm{kgf} / \mathrm{cm}^{2}\right)$ & $* *$ & $* *$ \\
\hline
\end{tabular}

** Highly significantly different $(\mathrm{P} \leq 0.01)$; NS, not significantly different.

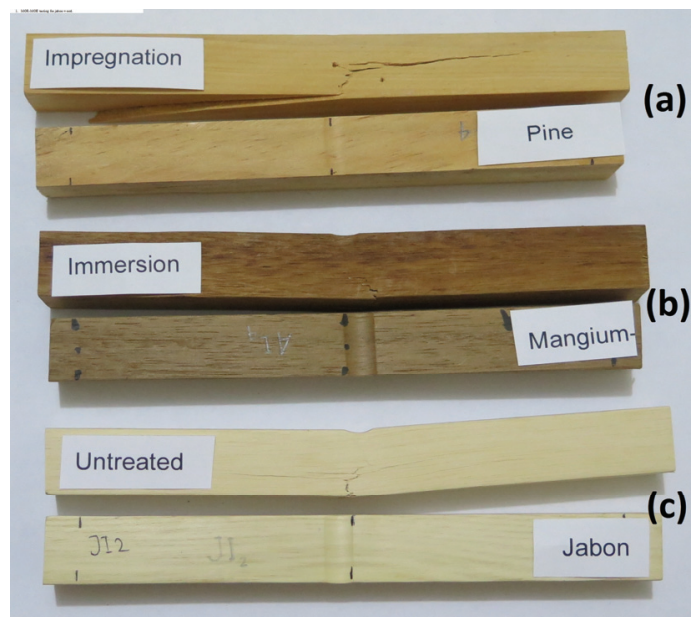

Fig. 2. MOR-MOE tested wood specimens: (a) MMA impregnated pine, (b) MMA immersed mangium, and (c) untreated jabon.

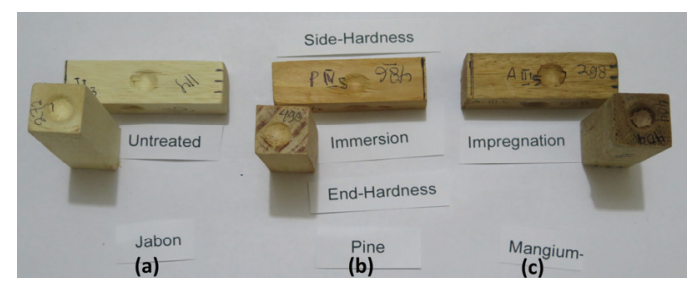

Fig. 3. Side- and end-hardness tested wood specimens: (a) untreated jabon, (b) MMA immersed pine, and (c) MMA impregnated mangium.

As shown in Table 7, wood species, treatment and interaction between wood species and treatment factors are shown to have affected mechanical properties of the wood, but the interaction factor did not significantly affect end hardness. According to Table 6, the mech- anical properties of jabon which were having the lowest values were different from those of mangium and pine because the density of jabon $\left(0.37 \mathrm{~g} / \mathrm{cm}^{3}\right)$ was much lower than those of mangium $\left(0.61 \mathrm{~g} / \mathrm{cm}^{3}\right)$ and pine $\left(0.70 \mathrm{~g} / \mathrm{cm}^{3}\right)$. Jabon had the lowest density, reflecting that it had the highest void space and smallest amount of cell wall material, and consequently the lowest mechanical properties. Furthermore, mangium and pine were different significantly in terms of mechanical properties except for MOR, and pine had higher valueand different from mangium.

Regarding to Table 6 untreated jabon wood, with an MOR of $426 \pm 29 \mathrm{kgf} / \mathrm{cm}^{2}$, belonged to strength class IV according to Strength Classification of Indonesian Wood (Table 1), and the two other woods belonged to strength class III or higher class. The MMA-treated wood from both theimmersion and impregnation processes had enhanced MOR, with jabon wood becoming strength class III and the two other wood species becoming strength class II. In short, all MMA woods (immersion process and impregnation process) became one strength class better.

MMA wood had enhanced MOE and hardness compared to untreated wood, and it was significantly different from untreated wood, but the MMA wood did not differ from each other based on process, except for end hardness and MOE of jabon. The density of MMA wood was higher than that of untreated wood, and it was more compact because the lumen or cell void was filled with MMA polymer. These results were 
in line with those of Olpan and Guven (2001), who reported that the presence of MMA polymer increased the mechanical properties of the wood. In addition, Wang et al. (2012) found that MMA wood had better mechanical properties than untreated wood in terms of MOR, MOE, compression strength, and hardness.

In summary, the mechanical properties of MMA wood were better than those of untreated wood. The MMA wood was one strength class better than untreated wood. Furthermore, it could be resumed that immersion process was better than impregnation process in terms of mechanical properties. Referring to Wang et al. (2012) who reported that the degree of polymer loading affected physical and mechanical properties linearly, it could be assumed that in the future works impregnation process could get better result by higher polymer loading, and this matter could be reached through a higher and longer in the vacuum and pressure processes.

\section{CONCLUSION}

The physical and mechanical properties of wood were affected by wood species and the presence of MMA. Higher wood density yielded better the properties than lower wood density. The average polymer loading reached $18.7 \%$ with the impregnation process and $11.0 \%$ with the immersion process. Physical and mechanical properties of MMA wood were enhanced compared to untreated wood, as shown by lower values for moisture content, shrinkage, and water absorption, but higher values for MOR, MOE, side hardness, and end hardness. Furthermore, the impregnation process was better than immersion process resulting the physical and mechanical properties. Based on MOR values, the MMA woods were one strength class higher compared to untreated wood with regard to Strength Classification of Indonesian Wood.

\section{ACKNOWLEDGMENT}

The authors would like to express our great appreciation to the Indonesian Ministry of Research, Technology, and Higher Education, which sponsored the research through Priority Basic Research of the University Grant (Penelitian Dasar Unggulan Perguruan Tinggi), and to Directorate General Research Strengthening and Development (Ditjen Penguatan Riset dan Pengembangan Kemenristekdikti) to attend Society of Wood Science and Technology Conference in Nagoya Japan 2018 via Program Bantuan Seminar Luar Negeri. The authors also would like to express our gratefulness to IPB University (Bogor Agricultural University), Bogor, Indonesia, for research facilities.

\section{REFERENCES}

[ASTM] American Society forTesting Materials. 1992. Direct moisture content measurement of wood and wood-base materials (ASTM D4442-92). ASTM International, West Conshohocken, PA.

[ASTM] American Society for Testing Materials. 2007. Specific gravity of wood and wood-based materials (ASTM D2395-07). ASTM International, West Conshohocken, PA.

[BS] British Standard. 1957. Methods of testing small clear specimens of timber (BS 373:1957).

Cho, N.S., Jo, J.M., Ahn, W.Y. 1974. On the manufacturing of WPC (Wood Plastic Composites) with heat catalyst polymerization (I) On the characteristics of composites made from monomer methyl methacrylate and several commercial woods in Korea. J. of Korean Wood Science and Technology 2(3): 3-16

Ding, W.D., Koubaa, A., Chaala, A., Belem, T., Krause, C. 2008. Relationship between wood porosity, wood density and methyl methacrylate impregnation rate. Wood Material Science \& Engi- 
neering 3(1-2): 62-67.

Ding, W.D., Koubaaa, A., Chaala, A. 2012. Dimensional stability of methyl methacrylate hardened hybrid poplar wood. BioResources 7(1): 504-520.

Fajriani, E., Ruelle, J., Dlouha, J., Fournier, M., Hadi, Y.S., Darmawan, W. 2013. Radial variation of wood properties of sengon (Paraserianthes falcataria) and jabon (Anthocephalus cadamba). J. Indian Academy of Wood Science. 10(2): 110-117.

Hadi, Y.S., Darma, I.G.K.T., Febrianto, F., Herliyana, E.N. 1995. Acetylated rubber-wood flakeboard resistance to bio-deterioration. Forest Products Journal 45(10): 64-66.

Hadi, Y.S., Nawawi, D.S., Herliyana, E.N., Lawniczak, M. 1998. Termite attack resistance of four polystyrene impregnated woods from Poland. Forest Products Journal 48(9): 60-62.

Hadi, Y.S., Westin, M., Rasyid, E. 2005. Resistance of furfurylated wood to termite attack. Forest Products Journal 55(11): 85-88.

Hadi, Y.S., Hadjib, N., Utama, M. 2008. Effect of urea concentration and vacuum treatment on physical and mechanical properties of methyl methacrylate bamboo. Molecular Crystals and Liquid Crystals 484: 151-156.

Hadi, Y.S., Rahayu, I.S., Danu, S. 2013. Physical and mechanical properties of methyl methacrylate impregnated jabon wood. Journal of the Indian Academy of Wood Science 10(2): 77-80.

Hadi, Y.S., Massijaya, M.Y., Hermawan, D., Arinana, A. 2015a. Feeding rate of termites in wood treated with borax, acetylation, polystyrene, and smoke. Journal of the Indian Academy of Wood Science 12(1): 74-80.

Hadi, Y.S., Rahayu, I.S., Danu, S. 2015b. Termite resistance of jabon wood impregnated with methyl methacrylate. Journal of Tropical Forest Science 27: 25-29.

Hadi, Y.S., Massijaya, M.Y., Zaini, L.H., Abdillah, I.B.,
Arsyad, W.O.M. 2018. Resistance of methyl methacrylate impregnated wood to subterranean termite attack. Journal of the Korean Wood Science and Technology 46(6): 748-755.

Hartono, R., Hidayat, W., Wahyudi, I., Febrianto, F., Dwianto, W., Jang, J.H., Kim, N.H. 2016. Effect of phenol formaldehyde impregnation on the physical and mechanical properties of soft-inner part of oil palm trunk. Journal of the Korean Wood Science and Technology 44 (6): 842-851.

Hendrik, J., Hadi, Y.S., Massijaya, M.Y., Santoso, A. 2016. Properties of laminated panels made from fast-growing species glued with mangium tannin adhesive. BioResources 11(3): 5949- 5960.

Islam, M.S., Hamdan, S., Jusoh,I., Rahman, M.R., Talib, Z.A. 2011. Dimensional stability and dynamic Young's modulus of tropical light hardwood chemically treated with methyl methacrylate in combination with hexamethylene diisocyanate cross-linker. Industrial \& Engineering Chemistry Research (2011)50: 3900-3906.

Koubaa, A., Ding, W.D., Chaala,A., Bouafif, H. 2012. Surface properties of methyl methacrylate hardened hybrid poplar wood. Journal of Applied Polymer Science 123: 1428-1436.

Lee, W.Y. 1983. Plastic combination on the penetration of MMA polymer and dimensional stability. Journal of the Korean Wood Science and Technology 11(3): 49-57.

Martawijaya, A., Kartasujana, I., Kadir, K., Prawira, S.A. 2005. Atlas Kayu Indonesia (Indonesian Wood Atlas). Ministry of Forestry, Forestry Development and Research Agency, Bogor, Indonesia.

Ministry of Environment and Forestry. 2017. Statistic of Indonesian Forestry. Jakarta, Indonesia.

Olpan, D., Guven, O. 2001.Modification of some mechanical properties of spruce by radiation induced copolymerization of acrylonitrile and methyl methacrylate with allyl glycidyl ether. 
Polymer. Composites 22(1): 90-96.

Prabawa, S.B. 2005. The physical and fiber dimension properties of 4-year old mangium wood from Sebulu of East Kalimantan. Jurnal Penelitian Hasil Hutan (Forest Products Research Journal) 23(5): 339-348.

Wang, X., Cui, Y., Zhang, H., Xie, B. 2012.Effects of methyl methacrylate grafting and polyamide coating on the interfacial behavior and mechanical properties of jute-fiber-reinforced polypropylene composites. Journal of Vinyl and Additive Technology 18(2):113-119.

Won, K.R., Hong, N.E., Park, H.M., Byeon, H,S,. 2016. Evaluation of sapwood and heartwood decay resistance after immersion treatment with pyroligneous liquor. Journal of the Korean Wood Science and Technology 44(6): 880-889. 